\title{
Methodiek schoolverlatersinformatiesysteem 2001
}

\author{
Citation for published version (APA):
}

Huijgen, T. G. (2002). Methodiek schoolverlatersinformatiesysteem 2001. Researchcentrum voor Onderwijs en Arbeidsmarkt, Faculteit der Economische Wetenschappen. ROA Working Papers No. 3 https://doi.org/10.26481/umarow.2002003

Document status and date:

Published: 01/01/2002

DOI:

10.26481/umarow.2002003

Document Version:

Publisher's PDF, also known as Version of record

\section{Please check the document version of this publication:}

- A submitted manuscript is the version of the article upon submission and before peer-review. There can be important differences between the submitted version and the official published version of record.

People interested in the research are advised to contact the author for the final version of the publication, or visit the DOI to the publisher's website.

- The final author version and the galley proof are versions of the publication after peer review.

- The final published version features the final layout of the paper including the volume, issue and page numbers.

Link to publication

\footnotetext{
General rights rights.

- You may freely distribute the URL identifying the publication in the public portal. please follow below link for the End User Agreement:

www.umlib.nl/taverne-license

Take down policy

If you believe that this document breaches copyright please contact us at:

repository@maastrichtuniversity.nl

providing details and we will investigate your claim.
}

Copyright and moral rights for the publications made accessible in the public portal are retained by the authors and/or other copyright owners and it is a condition of accessing publications that users recognise and abide by the legal requirements associated with these

- Users may download and print one copy of any publication from the public portal for the purpose of private study or research.

- You may not further distribute the material or use it for any profit-making activity or commercial gain

If the publication is distributed under the terms of Article $25 \mathrm{fa}$ of the Dutch Copyright Act, indicated by the "Taverne" license above, 


\section{Methodiek Schoolverlatersinformatiesysteem 2001}

ROA-W-2002/3

Timo Huijgen

Researchcentrum voor Onderwijs en Arbeidsmarkt

Faculteit der Economische Wetenschappen en Bedrijfskunde Universiteit Maastricht

Maastricht, oktober 2002 
ISBN 90-5321-343-0

Sec02.155.doc 
Inhoud

Bladzijde

Voorwoord

1 Inleiding 1

2 Schoolverlatersonderzoeken 1

3 Dataverwerking en weging 3

4 Dekkingsgraad en respons $\quad 7$

5 Non-respons 13

6 Besluit 18

$\begin{array}{lr}\text { Literatuur } & 19\end{array}$

$\begin{array}{ll}\text { Appendix A: Kernvragenlijst } & 21\end{array}$ 



\section{Voorwoord}

Dit werkdocument gaat in op de methodiek die in het uitvoeringsjaar 2001 gehanteerd wordt binnen het schoolverlatersonderzoek zoals dat door het ROA wordt uitgevoerd. Het betreft de enquêtes Registratie van Uitstroom en Bestemming van Schoolverlaters (RUBS), HBO-Monitor en WO-Monitor. Deze enquetes zijn sinds 1996 in vergaande mate geï ntegreerd in het Schoolverlatersinformatiesysteem (SIS), waardoor een vergelijkbaar systeem ontstaan is met gegevens over schoolverlaters uit vrijwel het gehele secundair en tertiair onderwijs. In het kader van het onderzoek binnen dit informatiesysteem is onder andere het rapport en de statistische bijlage van Schoolverlaters tussen onderwijs en arbeidsmarkt 2001 gepubliceerd. Daarnaast zijn er nog vier specifieke rapportages, te weten een rapport over de arbeidsmarktpositie van afgestudeerden van het $\mathrm{HBO}$, een rapport over de arbeidsmarktpositie van afgestudeerden van het kunstvakonderwijs, een rapport over afgestudeerden van de lerarenopleidingen en een rapport over de afgestudeerden van het WO.

SIS 2001 is financieel mogelijk gemaakt door de Ministeries van Onderwijs, Cultuur en Wetenschappen, Sociale Zaken en Werkgelegenheid en Landbouw, Natuurbeheer en Visserij, het Expertisecentrum voor Loopbaanvraagstukken LDC, de HBO-Raad, de VSNU en de deelnemende onderwijsinstellingen. Bij de uitvoering van het onderzoek is samengewerkt met DESAN Research Solutions te Amsterdam en STOAS Onderzoek te Wageningen. Binnen het ROA is de projectleiding van SIS in handen van dr. R.K.W. van der Velden en dr. M.H.J. Wolbers. Dit werkdocument is samengesteld door drs. T.G. Huijgen. Verder hebben aan SIS 2001 meegewerkt: dr. J.P. Allen, P.J.E.G. van der Kolk, E.J. Potma, drs. G.W.M. Ramaekers, E.M.H.P. Soudant en dr. H.F. Vaatstra (allen werkzaam bij ROA), alsmede drs. M.C.M.Th. van Alphen, drs. H. van Dongen en drs. R. Tjemmes (allen werkzaam bij DESAN Research Solutions). 



\section{Inleiding}

Door het ROA worden jaarlijks drie grootschalige schoolverlatersonderzoeken uitgevoerd. In de eerste plaats betreft dit een onderzoek onder de schoolverlaters van het algemeen voortgezet onderwijs (AVO), het voorbereidend beroepsonderwijs (VBO) ${ }^{1}$, de beroepsopleidende leerweg $(B O L)$ en de beroepsbegeleidende leerweg (BBL) van het secundair beroepsonderwijs aan de hand van de enquête Registratie van Uitstroom en Bestemming van Schoolverlaters (RUBS). In de tweede plaats is dit een onderzoek onder de afgestudeerden van het Hoger Beroepsonderwijs (HBO) via de HBO-Monitor. In de derde plaats wordt onderzoek verricht onder de afgestudeerden van de universiteiten (WO-Monitor). Samen vormen deze schoolverlatersonderzoeken de basis voor een aantal landelijke publicaties, zoals het rapport en de statistische bijlage Schoolverlaters tussen onderwijs en arbeidsmarkt 2001 en de rapporten De arbeidsmarktpositie van afgestudeerden van het hoger beroepsonderwijs; HBO-Monitor 2001, De arbeidsmarktpositie van afgestudeerden van het Kunstenonderwijs; Kunsten-Monitor 2001; $\mathrm{Na}$ (ar) de lerarenopleiding; Onderwijsmonitor 2001 en de WO-Monitor 2000 en 2001.

Dit werkdocument vormt een methodologische verantwoording op de reeds verschenen en nog te verschijnen rapporten. Er zal met name worden ingegaan op de gehanteerde methodiek, de respons en het uitgevoerde non-responsonderzoek. De opzet van dit werkdocument is als volgt. Allereerst wordt in paragraaf 2 een uiteenzetting gegeven over het doel en de opzet van de schoolverlatersonderzoeken. In paragraaf 3 wordt ingegaan op de dataverwerking en de weging van de gegevens. Vervolgens wordt in paragraaf 4 een overzicht gegeven van de dekkingsgraad en de respons. Paragraaf 5 bevat een verslag van het non-responsonderzoek. Ten slotte worden in paragraaf 6 de belangrijkste conclusies van dit werkdocument kort samengevat.

\section{Schoolverlatersonderzoeken}

Doel

De schoolverlatersenquêtes van het ROA zijn gericht op het monitoren en analyseren van de bestemming van gediplomeerde schoolverlaters in het vervolgonderwijs en op de arbeidsmarkt. Daarbij kunnen twee componenten worden onderscheiden: een toepassingscomponent en een onderzoekscomponent. De toepassingscomponent richt zich op de zorg van individuele onderwijsinstellingen voor de onderwijskwaliteit en de afstemming van het onderwijs op de behoeften van de arbeidsmarkt. Daarvoor worden zogenaamde instellingsrapportages opgesteld waarin de onderwijsinstellingen informatie krijgen over hun eigen afgestudeerden, waar relevant afgezet tegen het landelijke beeld. Hiermee kunnen management, studierichtingsleiders en decanaat een indruk krijgen van het externe rendement van hun opleidingen.

De onderzoekscomponent van het schoolverlatersonderzoek, aangeduid als het Schoolverlatersinformatiesysteem (SIS), heeft als doel het analyseren van het doorstroompatroon van schoolverlaters naar vervolgonderwijs en het transitieproces van school naar werk. De resultaten

1. Inclusief het individueel voorbereidend beroepsonderwijs (IVBO). 
hiervan worden onder meer gepubliceerd via algemeen toegankelijke landelijke rapportages. Hierin ligt het accent op (ontwikkelingen in) het intredeproces van schoolverlaters, de kansen op het vinden van werk, de kwaliteit van het werk en het keuzegedrag van schoolverlaters ten aanzien van mogelijke vervolgopleidingen en de kwaliteit van de aansluiting die daarbij wordt ondervonden.

\section{Opzet}

Zoals is aangegeven vormt een drietal schoolverlatersonderzoeken (RUBS, HBO-Monitor en WO-Monitor) de basis van SIS. Voor al deze schoolverlatersonderzoeken geldt dat onderwijsinstellingen zelf aangeven of zij met (een deel van) hun schoolverlaters of afgestudeerden willen deelnemen. De RUBS-enquête wordt bij de scholen aangeboden onder verantwoordelijkheid van het ROA. De HBO-Monitor en de Kunstenmonitor worden bij de hogescholen aangeboden onder auspiciën van de HBO-Raad. De WO-Monitor vindt in VSNU-verband plaats. Het ROA draagt zorg voor de uitvoering van de WO-Monitor voor tien universiteiten en heeft daarnaast de landelijke coördinatie. De Rijksuniversiteit Groningen, de Katholieke Universiteit Nijmegen en de Universiteit Twente voeren de enquête momenteel zelf uit. Ook de gegevens van deze 'lokale' uitvoerders zijn opgenomen in SIS. Binnen het agrarisch onderwijs worden de resultaten van de onderzoeken aangeboden door STOAS Onderzoek te Wageningen.

Door bovengenoemde werkwijze is er niet persé sprake van een aselecte steekproef. Met name bij de RUBS-enquête is de dekkingsgraad niet altijd even hoog (zie paragraaf 4). Mochten er 'witte vlekken' in de deelname aan RUBS ontstaan - zowel naar opleidingsrichting als regio dan wordt hier een aanvullende steekproef getrokken.

Sinds het uitvoeringsjaar 1996 wordt het schoolverlatersonderzoek van het ROA uitgevoerd volgens een geï ntegreerd model, waarbij één meetmoment en één kernvragenlijst wordt onderscheiden. In de periode september-december 2001 zijn ongeveer 100.000 schoolverlaters en afgestudeerden van het school-/studiejaar 1999/2000 benaderd met een schriftelijke vragenlijst. Dezelfde vragenlijst werd voor een aantal opleidingen ook via internet beschikbaar gesteld, zodat de schoolverlaters konden kiezen op welke manier ze de vragenlijst wilden invullen. Wanneer schoolverlaters na ruim een maand de vragenlijst nog niet hebben ingevuld, wordt een rappel verstuurd.

Hoewel de vragenlijsten in de kern gelijk zijn, is ook in het uitvoeringsjaar 2001 enige variatie aan vragen tussen de verschillende vragenlijsten. Hiermee wordt recht gedaan aan de verschillen die er tussen de diverse onderwijsniveaus of -sectoren bestaan.

Binnen RUBS zijn aparte lijsten gebruikt voor de schoolverlaters van MAVO/HAVO/VWO, (I)VBO, MBO-BOL en MBO-BBL. Bovendien zijn voor het agrarisch onderwijs op zowel (I)VBOals MBO-niveau specifieke vragenlijsten gebruikt. Binnen de HBO-Monitor is een aparte vragenlijst opgesteld voor de afgestudeerden van het landbouwonderwijs en het pedagogisch onderwijs. Daarnaast is onder de naam Kunsten-Monitor een specifieke vragenlijst opgesteld voor afgestudeerden van de HBO sector Taal en Cultuur. In het kader van de WO-Monitor zijn 
er, naast de standaard WO-vragenlijst, aparte vragenlijsten opgesteld voor het pedagogisch onderwijs en het agrarisch onderwijs (afgestudeerden van de Wageningen Universiteit).

Om een hogere respons te bereiken, is onder HBO-afgestudeerden van het kunstonderwijs die de schriftelijke vragenlijst niet hebben teruggestuurd (een deel van) de vragenlijst alsnog telefonisch afgenomen. De afgestudeerden van het pedagogisch onderwijs, op HBO en WOniveau, die in eerste instantie niet hebben gereageerd op de schriftelijke enquête, zijn eveneens naderhand telefonisch benaderd.

De vragenlijsten van het uitvoeringsjaar 2001 bestaan uit een viertal hoofdonderwerpen: algemeen (geslacht, leeftijd e.d.), onderwijsloopbaan, arbeidsmarktintrede en een thematisch gedeelte. ${ }^{2}$ Binnen de vragenlijsten voor het AVO en het (I)VBO ligt de nadruk op de doorstroom naar het vervolgonderwijs en de redenen van eventuele voortijdige uitval. Tevens wordt in deze vragenlijsten uitgebreid stilgestaan bij de rol van studie- en beroepskeuzebegeleiding. Er wordt slechts in beperkte mate aandacht besteed aan de arbeidsmarktintrede van deze groep schoolverlaters. In de overige vragenlijsten ligt de nadruk juist op het transitieproces van school naar werk en wordt minder vergaand gevraagd over de doorstroom naar vervolgonderwijs.

\section{Dataverwerking en weging}

Het versturen van alle vragenlijsten, het beschikbaar stellen van de vragenlijsten op internet, het verzorgen van de rappels en de verwerking van de binnengekomen vragenlijsten wordt uitgevoerd door DESAN Research Solutions te Amsterdam. Bij de verwerking worden de vragenlijsten ingevoerd of gescand, de open vragen gecodeerd (waaronder vervolgopleiding, beroep, bedrijfssector) en de eerste bestandscontroles en correcties uitgevoerd. Het ROA voert daarna een datacleaning uit op verwijzingsstructuur en op onderlinge consistenties. Vervolgens worden nieuwe, samengestelde variabelen aangemaakt en wordt het bestand gewogen, zodat op basis van de gegevens landelijk representatieve uitspraken kunnen worden gedaan.

\section{Dataverwerking}

De vragenlijsten bevatten voor het merendeel gesloten antwoordcategorieën, waarbij de respondenten kunnen kiezen uit een aantal voorgelegde mogelijkheden. In een beperkt aantal gevallen dienen de schoolverlaters zelf een numerieke waarde in te vullen, bijvoorbeeld bij leeftijd, inkomen en aantal gewerkte uren. Bij enkele andere vragen wordt gebruik gemaakt van een volledig open vraagstelling, waarbij de schoolverlaters zelf het antwoord op de vraag moeten omschrijven. Dit is met name het geval bij vragen over:

- soort opleiding (voor- of vervolgopleiding);

- beroep;

- bedrijfssector;

- gemeente (woon- of werkgemeente).

2. Zie bijlage A voor een overzicht van het kerndeel van de vragenlijst. 
Bij deze vragen worden de alfanumerieke antwoorden van de respondenten gecodeerd volgens vooraf opgestelde classificaties. Voor de opleidingsvragen wordt daarbij gebruik gemaakt van een speciaal voor dit doel door het ROA opgestelde opleidingsclassificatie, waarin alle in Nederland voorkomende (reguliere) opleidingen zijn opgenomen. ${ }^{3}$ Beroep en bedrijfssector worden gecodeerd volgens de Standaard Beroepen Classificatie 1992 (SBC '92) en de Standaard Bedrijfsindeling 1993 (SBI '93) van het CBS. Overigens zijn beide classificaties, waar relevant, door het toevoegen van een extra digit verder verbijzonderd. Gemeenten worden gecodeerd volgens de gemeentecodes die door het CBS in het meest recente Plaatsnamenregister worden gehanteerd.

$\mathrm{Na}$ de data-entry of het scannen van de vragenlijsten worden de aldus verkregen ruwe gegevens door DESAN onderworpen aan een eerste kwaliteitscontrole. DESAN stelt het onderzoeksbestand samen en controleert op cruciale variabelen zoals uniek casenummer, schoolnummer, opleiding, respons, voltijd/deeltijd opleiding en diplomabezit. Deze variabelen worden onderling en met de variabele 'vragenlijst' op elkaar afgestemd. Bijvoorbeeld: komt een bepaalde (vol- of deeltijd) opleiding voor op een school, is voor een opleiding de juiste vragenlijst gehanteerd, is de vragenlijst grotendeels (met valide waarden) ingevuld, zijn de afgestudeerden ook gediplomeerd e.d. Na deze eerste controle geeft DESAN het onderzoeksbestand aan het ROA, waar vervolgens de volgende controles en correcties uitgevoerd worden:

1. Controle op variabelen met "anders-categorie": hierin wordt bekeken of er bij de vragen met een antwoordcategorie "anders, namelijk..." bepaalde overeenkomstige antwoorden kunnen worden onderscheiden zodat vervolgens eventuele nieuwe antwoordcategorieën worden aangemaakt of dat de "anders-categorie" teruggebracht kan worden naar een al bestaande antwoordcategorie (dit laatste is vaak het geval bij de vraag over de maatschappelijke positie van de respondent).

2. Doorvoeren van de verwijzingsstructuur: zijn er na een verwijzingsvraag 3 of meer vervolgvragen ingevuld dan wordt, indien nodig, het antwoord op de verwijzingsvraag aangepast zodat de verwijzing opgevolgd wordt. Zijn er minder dan 3 vervolgvragen na de verwijzing dan geldt dat alle vervolgvragen een geldig antwoord moeten hebben voordat een eventuele correctie op de desbetreffende verwijzingsvraag plaatsvindt. Zodoende garandeert de verwijzingsvraag altijd een juist aantal cases op de vervolgvragen. Verder wordt er een aparte code toegepast op vragen die wel beantwoord hadden moeten worden, maar die de respondent niet heeft ingevuld (zogenaamde 'user-missing'). Vragen die de respondent door een eventuele verwijzing niet hoeft in te vullen blijven leeg (d.w.z. op 'system-missing' staan).

3. Afronding cleaning: tot slot van de cleaning worden de cases die niet bruikbaar zijn uit het bestand verwijderd. Dit zijn onder andere de cases waarvan de afstudeerperiode niet correct is of cases waarvan meerdere cruciale basisvariabelen ontbreken.

3. Daarbij is een rechtstreekse koppeling mogelijk met de Standaard Onderwijs Indeling (SOI) van het CBS. 
$\mathrm{Na}$ de cleaning wordt het onderzoeksbestand uitgebreid met een aantal nieuwe samengestelde variabelen. Dit zijn variabelen die specifiek zijn gedefinieerd en/of op meerdere variabelen zijn gebaseerd (bijvoorbeeld de variabele 'beroepsbevolking').

\section{Weging}

De deelname van de scholen aan de schoolverlatersonderzoeken geschiedt zoals gezegd op vrijwillige basis. Hierdoor ontstaat er in de regel een ongelijke spreiding naar opleiding en regio. Ook naar andere kenmerken van de populatie kan er een niet-representatieve verdeling ontstaan. Zo is de respons bij vrouwen in het algemeen hoger dan bij mannen, waardoor vrouwen oververtegenwoordigd zijn in het onderzoeksbestand. Dergelijke omstandigheden leiden ertoe dat het onderzoeksbestand geen landelijke weergave is van de doelgroep. Om toch betrouwbare landelijke gegevens te kunnen presenteren, wordt een weging uitgevoerd op het bestand zoals dat na de dataverwerking is verkregen. Daarbij wordt een zodanige weging uitgevoerd dat de aantallen uiteindelijk corresponderen met de aantallen in de populatie.

Voor de weging wordt gebruik gemaakt van populatiegegevens die beschikbaar zijn op basis van de Integrale Leerlingtelling (ILT) (voor wat betreft het AVO, (I)VBO, BOL en BBL) en het Centraal Register Instellingen Hoger Onderwijs (CRIHO) (betreffende het HBO). Beide databestanden worden beheerd door het Ministerie van Onderwijs, Cultuur en Wetenschappen. De populatiegegevens van HBO Taal en Cultuur zijn echter niet gebaseerd op de CRIHO-data. Deze bleek niet volledig betrouwbaar voor deze sector. Als populatie is daarom het totale aantal uitgezette vragenlijsten per kunstopleiding gebruikt. Dit is mogelijk omdat van de opleidingen die in de steekproef zitten iedereen benaderd wordt. Ten aanzien van de schoolverlaters van de landbouwopleidingen wordt gebruik gemaakt van overeenkomstige gegevens beschikbaar gesteld door het Ministerie van Landbouw, Natuurbeheer en Visserij. Voor wat betreft de WOopleidingen ten slotte wordt geen weging, maar alleen een ophoging toegepast. De reden hiervoor is dat iedere afgestudeerde van het WO wordt benaderd en er dus geen sprake is van een steekproef.

De ILT 1999/2000 heeft per instelling en per opleiding gegevens beschikbaar over het aantal leerlingen per leerjaar en geslacht. ${ }^{4} \mathrm{Het} \mathrm{CRIHO}$ bevat per instelling en opleiding gegevens over het aantal diploma's, waarbij eveneens een onderverdeling naar geslacht is gemaakt. Er wordt op het niveau van opleiding $x$ regio $x$ geslacht een weegfactor bepaald die de verhouding aangeeft tussen het populatie-aantal en het aantal respondenten in het onderzoeksbestand. Bij de weging van $\mathrm{HBO}$-opleidingen wordt bovendien een onderscheid gemaakt tussen voltijd- en deeltijdopleidingen. Voor een aantal opleidingen heeft voorafgaand aan de weging een clustering van opleidingen plaatsgevonden. Op dit hogere clusterniveau wordt vervolgens de weging uitgevoerd. Gewogen wordt op het niveau van opleiding x voltijd/deeltijd (alleen HBO) x regio $x$ geslacht. Indien de resulterende weegfactor groter is dan 3 maal de gemiddelde weegfactor en als bovendien de steekproef kleiner is dan 50 , dan wordt het kenmerk geslacht en indien noodzakelijk ook het kenmerk regio buiten beschouwing gelaten. In dat geval wordt

4. Helaas zijn gegevens over het aantal gediplomeerden vanwege privacy-redenen tegenwoordig niet meer beschikbaar. Om die reden is het aantal gediplomeerden gebaseerd op het rendement van het laatste leerjaar berekend op de ILT-gegevens van het jaar daarvoor. 
gewogen op het niveau van opleiding $x$ voltijd/deeltijd (alleen HBO) $x$ regio, respectievelijk opleiding $x$ voltijd/deeltijd (alleen HBO). Tabel 3.1 geeft een overzicht van de aantallen schoolverlaters per opleidingssector vóór en ná de weging. Bij het HBO is daarbij een onderscheid gemaakt naar voltijd en deeltijd.

Tabel 3.1

Aantallen schoolverlaters per opleidingssector zowel voor weging als na weging

Opleidingssector

$\begin{array}{cc}\begin{array}{c}\text { Ongewogen } \\ \text { aantal }\end{array} & \begin{array}{c}\text { Gewogen } \\ \text { aantal }\end{array}\end{array}$

\begin{tabular}{|c|c|c|}
\hline $\begin{array}{l}\text { AVO } \\
\text { MAVO } \\
\text { HAVO } \\
\text { VWO }\end{array}$ & $\begin{array}{l}4.109 \\
1.513 \\
1.484 \\
1.112\end{array}$ & $\begin{array}{l}97.000 \\
40.900 \\
32.700 \\
23.400\end{array}$ \\
\hline $\begin{array}{l}\text { VBO } \\
\text { IVBO } \\
\text { landbouw } \\
\text { techniek } \\
\text { economie } \\
\text { gezondheidszorg }\end{array}$ & $\begin{array}{r}1.486 \\
240 \\
462 \\
296 \\
247 \\
241\end{array}$ & $\begin{array}{r}35.600 \\
4.700 \\
2.200 \\
12.200 \\
7.300 \\
9.200\end{array}$ \\
\hline $\begin{array}{l}\text { BOL niveau } 1 / 2 \\
\text { landbouw } \\
\text { techniek } \\
\text { economie } \\
\text { gezondheidszorg }\end{array}$ & $\begin{array}{r}869 \\
44 \\
186 \\
490 \\
149\end{array}$ & $\begin{array}{r}13.300 \\
250 \\
2.300 \\
8.100 \\
2.700\end{array}$ \\
\hline $\begin{array}{l}\text { BOL niveau } 3 / 4 \\
\text { landbouw } \\
\text { techniek } \\
\text { economie } \\
\text { gezondheidszorg } \\
\text { gedrag en maatschappij }\end{array}$ & $\begin{array}{r}4.969 \\
631 \\
1.284 \\
1.154 \\
816 \\
1.084\end{array}$ & $\begin{array}{r}39.600 \\
3.400 \\
10.000 \\
11.800 \\
5.900 \\
8.500\end{array}$ \\
\hline $\begin{array}{l}\text { BBL niveau } 1 / 2 \\
\text { landbouw } \\
\text { techniek } \\
\text { economie } \\
\text { gezondheidszorg }\end{array}$ & $\begin{array}{r}1.144 \\
151 \\
678 \\
225 \\
90\end{array}$ & $\begin{array}{r}19.100 \\
1.100 \\
11.200 \\
4.800 \\
2.000\end{array}$ \\
\hline $\begin{array}{l}\text { BBL niveau } 3 / 4 \\
\text { landbouw } \\
\text { techniek } \\
\text { economie } \\
\text { gezondheidszorg } \\
\text { gedrag en maatschappij }\end{array}$ & $\begin{array}{r}1.509 \\
148 \\
468 \\
320 \\
364 \\
209\end{array}$ & $\begin{array}{r}18.400 \\
800 \\
6.900 \\
3.700 \\
5.400 \\
1.600\end{array}$ \\
\hline $\begin{array}{l}\text { HBO voltijd } \\
\text { landbouw } \\
\text { onderwijs } \\
\text { techniek } \\
\text { economie }\end{array}$ & $\begin{array}{r}16.907 \\
838 \\
2.829 \\
3.329 \\
4.601\end{array}$ & $\begin{array}{r}44.500 \\
2.100 \\
6.900 \\
9.800 \\
13.000\end{array}$ \\
\hline
\end{tabular}


Tabel 3.1 (vervolg)

Aantallen schoolverlaters per opleidingssector zowel voor weging als na weging

\begin{tabular}{lrr}
\hline Opleidingssector & $\begin{array}{c}\text { Ongewogen } \\
\text { aantal }\end{array}$ & $\begin{array}{c}\text { Gewogen } \\
\text { aantal }\end{array}$ \\
\hline gezondheidszorg & 2.053 & 4.200 \\
gedrag en maatschappij & 2.447 & 5.800 \\
taal en cultuur & 810 & 2.700 \\
HBO deeltijd & 3.096 & 10.100 \\
landbouw & 36 & 100 \\
onderwijs & 1.006 & 3.900 \\
techniek & 190 & 600 \\
economie & 516 & 1.700 \\
gezondheidszorg & 598 & 1.500 \\
gedrag en maatschappij & 677 & 2.300 \\
taal en cultuur & 73 & 100 \\
& & \\
WO & 9.027 & 19.000 \\
landbouw & 208 & 500 \\
techniek & 1.137 & 2.500 \\
economie & 1.344 & 3.000 \\
gezondheidszorg & 1.136 & 2.500 \\
gedrag en maatschappij & 2.030 & 4.500 \\
taal en cultuur & 1.115 & 2.500 \\
recht en openbare orde & 1.322 & 2.900 \\
natuurwetenschappen & 735 & 1.600 \\
& & \\
\hline
\end{tabular}

\section{Dekkingsgraad en respons}

De schoolverlaters die uiteindelijk in het onderzoeksbestand zijn opgenomen, vormen slechts een gedeelte van de gehele onderzoekspopulatie. Enerzijds worden niet álle personen uit de doelgroep benaderd en anderzijds reageert niet iedereen die wél is benaderd. De dekkingsgraad geeft een beeld van de omvang van het gedeelte van de populatie dat benaderd is. Het responspercentage geeft vervolgens aan welk deel van degenen die benaderd zijn daadwerkelijk heeft gereageerd.

\section{Dekkingsgraad}

Tabel 4.1 laat voor 2001 zien hoe groot de dekkingsgraad per onderwijssoort is. ${ }^{5}$ Uit de tabel blijkt dat ertussen de onderwijssoorten een groot verschil in dekkingsgraad bestaat. De dekkingsgraad bij zowel het AVO als het (I)VBO is laag (respectievelijk 6\% en 10\%). Voor het

5. Scholen uit de regio Rotterdam hebben integraal meegedaan met RUBS 2001. Bij een deel van deze scholen was er echter onvoldoende informatie beschikbaar om vóór uitzetting van de vragenlijst te bepalen wat de gevolgde opleiding van de schoolverlater was. Omdat voor de non-responsgroep van deze scholen er dus geen bruikbare opleidingsgegevens zijn is ook de responsgroep van deze scholen vanaf paragraaf 4 bij de verdere analyses buiten beschouwing gelaten. 
AVO betekent dit een lichte daling, voor het (I)VBO een lichte stijging in vergelijking met 2000 . Ook BOL niveau 3/4 laat een daling van de dekkingsgraad zien ten opzichte van vorig jaar. De deelname bij alle overige onderwijssoorten is daarentegen toegenomen. Vooral de dekkingsgraden bij het $\mathrm{BBL}$ (beide niveaus) zijn toegenomen ten opzichte van vorig jaar. Bij het $\mathrm{HBO}$ is wederom sprake van een zeer hoge deelname, de dekkingsgraad is hier zelfs $83 \%$. De cijfers van de sector HBO Taal en Cultuur kunnen niet worden weergegeven, omdat de populatiegegevens gelijk zijn aan het aantal uitgezette vragenlijsten (zie paragraaf 3). Bij het WO zijn de cijfers niet weergegeven omdat alle afgestudeerden worden benaderd.

Tabel $4.1^{6}$

Dekkingsgraad per onderwijssoort

\begin{tabular}{|c|c|c|}
\hline Onderwijssoort & $\begin{array}{c}\text { Benaderd } \\
\text { aantal }\end{array}$ & $\begin{array}{c}\text { Dekking } \\
\%\end{array}$ \\
\hline $\begin{array}{l}\text { AVO } \\
\text { MAVO } \\
\text { HAVO } \\
\text { VWO }\end{array}$ & $\begin{array}{l}5.625 \\
2.223 \\
2.079 \\
1.323\end{array}$ & $\begin{array}{l}6 \\
5 \\
6 \\
6\end{array}$ \\
\hline $\begin{array}{l}\text { VBO } \\
\text { IVBO } \\
\text { landbouw } \\
\text { techniek } \\
\text { economie } \\
\text { gezondheidszorg }\end{array}$ & $\begin{array}{r}3.505 \\
653 \\
1.082 \\
818 \\
556 \\
396\end{array}$ & $\begin{array}{r}10 \\
14 \\
48 \\
7 \\
8 \\
4\end{array}$ \\
\hline $\begin{array}{l}\text { BOL niveau 1/2 } \\
\text { landbouw } \\
\text { techniek } \\
\text { economie } \\
\text { gezondheidszorg }\end{array}$ & $\begin{array}{r}3.290 \\
136 \\
664 \\
2.052 \\
438\end{array}$ & $\begin{array}{l}24 \\
45 \\
29 \\
25 \\
16\end{array}$ \\
\hline $\begin{array}{l}\text { BOL niveau } 3 / 4 \\
\text { landbouw } \\
\text { techniek } \\
\text { economie } \\
\text { gezondheidszorg } \\
\text { gedrag en maatschappij }\end{array}$ & $\begin{array}{r}12.159 \\
1.461 \\
3.217 \\
3.305 \\
1.540 \\
2.636\end{array}$ & $\begin{array}{l}30 \\
41 \\
31 \\
28 \\
26 \\
31\end{array}$ \\
\hline $\begin{array}{l}\text { BBL niveau } 1 / 2 \\
\text { landbouw } \\
\text { techniek } \\
\text { economie } \\
\text { gezondheidszorg }\end{array}$ & $\begin{array}{r}4.754 \\
449 \\
2.930 \\
1.078 \\
297\end{array}$ & $\begin{array}{l}25 \\
42 \\
26 \\
22 \\
15\end{array}$ \\
\hline $\begin{array}{l}\text { BBL niveau } 3 / 4 \\
\text { landbouw } \\
\text { techniek } \\
\text { economie }\end{array}$ & $\begin{array}{r}4.746 \\
374 \\
1.787 \\
1.029\end{array}$ & $\begin{array}{l}25 \\
48 \\
26 \\
27\end{array}$ \\
\hline
\end{tabular}

6. Bij de cijfers van het $\mathrm{AVO}, \mathrm{VBO}, \mathrm{BOL}$ en $\mathrm{BBL}$ is er door de onvolledige gegevens bij enkele scholen uit de regio Rotterdam sprake van een lichte onderschatting (zie voetnoot 5 ). 
Tabel 4.1 (vervolg)

Dekkingsgraad per onderwijssoort

\begin{tabular}{lcc}
\hline Onderwijssoort & $\begin{array}{c}\text { Benaderd } \\
\text { aantal }\end{array}$ & $\begin{array}{c}\text { Dekking } \\
\%\end{array}$ \\
\hline BBL niveau 3/4 (vervolg) & & \\
gezondheidszorg & 1.007 & 18 \\
gedrag en maatschappij & 549 & 33 \\
$H B O^{7}$ & 43.038 & 83 \\
landbouw & 1.905 & 86 \\
onderwijs & 7.090 & 86 \\
techniek & 9.027 & 88 \\
economie & 12.848 & 93 \\
gezondheidszorg & 5.286 & 85 \\
gedrag en maatschappij & 6.882 & \\
\hline
\end{tabular}

Respons

Zoals uit tabel 4.2 blijkt is de respons ${ }^{8}$ het hoogst bij de schoolverlaters van het AVO (51\%). Het WO volgt met $46 \%$. Evenals voorgaande jaren is de respons van BBL niveau 1/2 (24\%) het laagst. De afgelopen jaren is er sprake van een dalende lijn in de responspercentages. Deze daling heeft zich in 2001 doorgezet voorzover het RUBS (AVO, VBO, BOL en BBL) en het WO betreft. De respons binnen het HBO lijkt zich enigszins te stabiliseren. Wat verder opvalt is dat er binnen iedere onderwijssoort sprake is van een vrij grote spreiding in de responspercentages. Met name bij het VBO zijn de verschillen tussen opleidingssectoren groot.

Door middel van een responsanalyse is geprobeerd een beter inzicht te krijgen in de factoren die van invloed zijn op de respons. Aangezien er (per definitie) vrij weinig gegevens bekend zijn over de schoolverlaters die niet gerespondeerd hebben, is de responsanalyse noodzakelijkerwijs beperkt. Er is informatie aanwezig over drie factoren die mogelijk invloed hebben op de respons. Ten eerste is informatie over de gevolgde opleiding van de aangeschreven schoolverlaters aanwezig. Ten tweede is de wijze van verzending van de vragenlijsten bekend. De vragenlijsten kunnen enerzijds centraal door DESAN aan de afgestudeerden worden toegestuurd; anderzijds kunnen de onderwijsinstellingen de vragenlijsten zelf verzenden. Dit laatste noemen we decentrale verzending. Ten derde is de regioverdeling in de steekproef bekend.

Wellicht geldt dat het responspercentage in de ene regio hoger ligt dan in de andere. Wanneer een bepaalde regio in de loop der jaren een steeds belangrijkere rol is gaan vervullen in de steekproef en als de respons tussen regio's inderdaad verschilt, dan kan dit een verklaring zijn voor veranderingen in de totale respons. Een soortgelijke situatie kan natuurlijk ook gelden voor het opleidingsniveau dat schoolverlaters hebben voltooid. Met behulp van een logistische regressie-analyse is nagegaan wat de invloed is van deze drie factoren op de respons. De resultaten van deze analyse staan weergegeven in tabel 4.3.

7. Exclusief HBO Kunst en Cultuur.

8. Voor de berekeningswijze van de respons zie Willems en Van der Linden (1998). 
Tabel 4.2

Responspercentage per opleidingssector

Opleidingssector $\%$

\begin{tabular}{|c|c|}
\hline $\begin{array}{l}\text { AVO } \\
\text { MAVO } \\
\text { HAVO } \\
\text { VWO }\end{array}$ & $\begin{array}{l}51 \\
48 \\
50 \\
60\end{array}$ \\
\hline $\begin{array}{l}\text { VBO } \\
\text { IVBO } \\
\text { landbouw } \\
\text { techniek } \\
\text { economie } \\
\text { gezondheidszorg }\end{array}$ & $\begin{array}{l}35 \\
34 \\
42 \\
27 \\
28 \\
44\end{array}$ \\
\hline $\begin{array}{l}\text { BOL niveau 1/2 } \\
\text { landbouw } \\
\text { techniek } \\
\text { economie } \\
\text { gezondheidszorg }\end{array}$ & $\begin{array}{l}26 \\
29 \\
27 \\
25 \\
32\end{array}$ \\
\hline $\begin{array}{l}\text { BOL niveau } 3 / 4 \\
\text { landbouw } \\
\text { techniek } \\
\text { economie } \\
\text { gezondheidszorg } \\
\text { gedrag en maatschappij }\end{array}$ & $\begin{array}{l}39 \\
43 \\
37 \\
32 \\
48 \\
43\end{array}$ \\
\hline $\begin{array}{l}\text { BBL niveau 1/2 } \\
\text { landbouw } \\
\text { techniek } \\
\text { economie } \\
\text { gezondheidszorg }\end{array}$ & $\begin{array}{l}24 \\
32 \\
24 \\
21 \\
30\end{array}$ \\
\hline $\begin{array}{l}\text { BBL niveau } 3 / 4 \\
\text { landbouw } \\
\text { techniek } \\
\text { economie } \\
\text { gezondheidszorg } \\
\text { gedrag en maatschappij }\end{array}$ & $\begin{array}{l}31 \\
37 \\
26 \\
29 \\
35 \\
36\end{array}$ \\
\hline $\begin{array}{l}\text { HBO } \\
\text { landbouw } \\
\text { onderwijs } \\
\text { techniek } \\
\text { economie } \\
\text { gezondheidszorg } \\
\text { gedrag en maatschappij } \\
\text { taal en cultuur }\end{array}$ & $\begin{array}{l}42 \\
49 \\
38 \\
40 \\
41 \\
51 \\
46 \\
30\end{array}$ \\
\hline $\begin{array}{l}\text { WO } \\
\text { landbouw } \\
\text { techniek } \\
\text { economie } \\
\text { gezondheidszorg } \\
\text { gedrag en maatschappij } \\
\text { taal en cultuur } \\
\text { recht en openbare orde } \\
\text { natuurwetenschappen }\end{array}$ & $\begin{array}{l}46 \\
56 \\
48 \\
40 \\
50 \\
50 \\
45 \\
42 \\
51\end{array}$ \\
\hline
\end{tabular}


Tabel 4.3

De invloed van onderwijssoort, regio en wijze van verzending op respons: logit effecten

\begin{tabular}{|c|c|c|}
\hline Onafhankelijke variabelen & Parameter & Standaardfout \\
\hline Constante & $-0,08^{* *}$ & 0,02 \\
\hline $\begin{array}{l}\text { Onderwijssoort: } \\
\text { AVO } \\
\text { VBO } \\
\text { BOL } 1 / 2 \\
\text { BOL } 3 / 4 \\
\text { BBL } 1 / 2 \\
\text { BBL } 3 / 4 \\
\text { HBO } \\
\text { WO }\end{array}$ & $\begin{array}{c}0,19^{\star *} \\
-0,44^{* *} \\
-0,88^{* *} \\
-0,30^{* *} \\
-1,01^{* *} \\
-0,68^{\star *} \\
-0,19^{* *}\end{array}$ & $\begin{array}{r}0,03 \\
0,04 \\
0,04 \\
0,02 \\
0,04 \\
0,04 \\
0,02\end{array}$ \\
\hline $\begin{array}{l}\text { Regio: } \\
\text { Noord } \\
\text { Oost } \\
\text { West } \\
\text { Zuid }\end{array}$ & $\begin{array}{c}0,05 \\
0,02 \\
-0,15^{\star *}\end{array}$ & $\begin{array}{r}0,03 \\
0,02 \\
0,02\end{array}$ \\
\hline $\begin{array}{l}\text { Decentrale verzending } \\
N=98.955\end{array}$ & $0,06^{\star *}$ & 0,02 \\
\hline
\end{tabular}

De analyse toont dat, gecorrigeerd voor regio en wijze van verzending, schoolverlaters van het AVO het vaakst responderen. Op de tweede plaats komen de afgestudeerden van het WO. De schoolverlaters van de kortere beroepsopleidingen responderen relatief gezien het minst vaak: de respons van BBL niveau 1/2 is het laagst, gevolgd door BOL niveau 1/2. Deze bevindingen zijn in overeenstemming met de gegevens uit tabel 4.2. Verder blijkt dat de respons geografisch ongelijkmatig verdeeld is. Met name in het Westen is de respons laag, in het Noorden van het land ligt de respons relatief gezien het hoogst. Daarnaast blijkt dat decentraal verzenden een significant hogere respons oplevert ten opzichte van centrale verzending van vragenlijsten. Dit laatste punt kan veroorzaakt worden door verschillende factoren. Zo kan het zijn dat respondenten zich meer betrokken voelen bij de enquête indien ze door de eigen school worden benaderd. Het is echter ook mogelijk dat de onderwijsinstellingen die de enquête zelf verzenden over betere adressenbestanden beschikken dan de instellingen die dit uitbesteden. Bij deze laatste groep instellingen zal een groter deel van de verstuurde vragenlijsten de schoolverlater nooit bereiken hetgeen uiteraard een lagere respons tot gevolg heeft.

Tabel 4.4 geeft tot slot een overzicht van de aantallen in 2001 uitgezette en teruggestuurde vragenlijsten. Dit overzicht geeft bovendien enkele redenen weer waarom sommige teruggestuurde vragenlijsten niet geschikt zijn voor verwerking. De belangrijkste reden hiervoor is het ontbreken van een juist adres (4\%). Onder overige redenen vallen met name afgestudeerden die onbereikbaar waren vanwege bijvoorbeeld een verblijf in het buitenland of ziekte. 
Tabel 4.4

Resultaat dataverzameling in aantallen per onderwijssoort

\begin{tabular}{|c|c|c|c|c|c|c|c|c|c|}
\hline & AVO & VBO & BOL $1 / 2$ & BOL $3 / 4$ & BBL 1/2 & BBL 3/4 & $\mathrm{HBO}$ & WO & Totaal \\
\hline Totaal benaderd & 5.625 & 3.537 & 3.290 & 12.160 & 4.754 & 4.746 & 46.274 & 20.106 & 100.492 \\
\hline Retour ontvangen & 2.995 & 1.351 & 1.098 & 5.300 & 1.403 & 1.725 & 22.983 & 10.134 & 46.989 \\
\hline - Waarvan geschikt voor verwerking & 2.792 & 1.180 & 786 & 4.452 & 1.080 & 1.391 & 20.313 & 9.084 & 41.078 \\
\hline \multicolumn{10}{|l|}{ - Waarvan niet geschikt voor verwerking: } \\
\hline • onbestelbaar retour & 76 & 82 & 87 & 311 & 137 & 168 & 2.011 & 778 & 3.650 \\
\hline - weigering: anonimiteit of andere reden & & & 9 & 5 & 3 & 9 & 33 & 21 & 80 \\
\hline - school-/studiejaar verkeerd & 32 & 12 & 10 & 44 & 11 & 11 & 103 & 51 & 274 \\
\hline • geen opleiding verlaten & 57 & 40 & 72 & 64 & 115 & 38 & 65 & & 451 \\
\hline - geen vitale informatie & 14 & 33 & 16 & 66 & 20 & 13 & 243 & 106 & 511 \\
\hline - overige redenen & 24 & 4 & 118 & 358 & 37 & 95 & 215 & 94 & 945 \\
\hline
\end{tabular}




\section{Non-respons}

Zoals uit tabel 4.2 is gebleken varieert het responspercentage tussen de $24 \%$ (BBL niveau 1/2) en $51 \%$ (AVO). De resultaten zoals die beschreven staan in de landelijke rapporten en instellingsrapportages hebben betrekking op deze responsgroep. Om te achterhalen of de onderzoeksresultaten die gebaseerd zijn op de gegevens van deze responsgroep geen vertekening van de werkelijkheid vormen, is het van belang na te gaan of er sprake is van een selectieve (non-)respons. Het mag niet zo zijn dat de groep respondenten en de groep nonrespondenten op kenmerken van elkaar verschillen. Als bijvoorbeeld de schoolverlaters die werkloos zijn grotendeels weigeren aan de enquête deel te nemen ontstaat er wat betreft het kenmerk werkloosheid een verschil tussen de non-responsgroep en de responsgroep. Dit zal vervolgens leiden tot een onderschatting van het werkelijke werkloosheidspercentage, indien dit wordt berekend op basis van de gegevens van de responsgroep.

Eventuele selectiviteit van de (non-)respons kan worden nagegaan door op enkele belangrijke kenmerken de responsgroep met de non-responsgroep te vergelijken. Dit is op twee manieren mogelijk:

1. door kenmerken van de responsgroep te vergelijken met kenmerken van de doelgroeppopulatie die reeds op basis van andere bronnen bekend zijn, of;

2. door een aanvullend onderzoek te houden onder de non-responsgroep, waarbij over enkele kernvariabelen informatie wordt ingewonnen.

Ten behoeve van het schoolverlatersonderzoek is vooraf nauwelijks enige informatie over de populatie bekend behalve over de gevolgde opleiding, het geslacht van de schoolverlaters en de regio van de opleiding. Deze populatiegegevens worden reeds gebruikt om het onderzoeksbestand te wegen waardoor op deze punten een landelijk representatief beeld ontstaat zodat voor het nagaan van de mate van selectiviteit van de (non-)respons derhalve een nonresponsonderzoek noodzakelijk is.

De vraag is vervolgens over welke kenmerken van de non-responsgroep informatie verzameld dient te worden. Het antwoord wordt bepaald door het belang dat binnen het schoolverlatersonderzoek aan verschillende kenmerken wordt gehecht en de mate waarin verwacht mag worden dat de respons op deze punten selectief is. De bestemming oftewel de maatschappelijke positie van schoolverlaters na het verlaten van de opleiding kan beschouwd worden als één van de belangrijkste kernpunten in de schoolverlatersenquêtes. Bovendien zou juist op dit punt selectiviteit in de (non-)respons kunnen ontstaan. Evenals in voorgaande jaren wordt daarom in de non-respons enquête voor het uitvoeringsjaar 2001 onder andere gevraagd naar de bestemming (maatschappelijke positie) van de schoolverlater.

Een ander belangrijk aspect binnen het schoolverlatersonderzoek omvat het onderzoek onder degenen die betaald werk verrichten. Daarom wordt in het non-responsonderzoek ook getoetst op eventuele selectiviteit in het antwoord op de vraag 'Heb je op dit moment (ook) betaald werk? (inclusief een betaalde bijbaan en/of een leer-arbeidsplaats)'. 
Het non-responsonderzoek voor 2001 heeft plaatsgevonden aan de hand van een korte telefonische enquête onder schoolverlaters van $A V O, V B O, B O L$ en $B B L$ en afgestudeerden van het $\mathrm{HBO}$ en het WO die in eerste instantie niet hebben gereageerd. Naar onderwijssoort wordt een gestratificeerde steekproef getrokken, dat wil zeggen een aselecte steekproef over de verschillende opleidingssectoren. Dit heeft geleid tot zo'n 1.900 respondenten in het nonresponsonderzoek. De opleidingssectoren HBO kunst en cultuur en HBO pedagogisch onderwijs vormen een uitzondering op deze steekproeftrekking: hier zijn de non-respondenten, zoals eerder is aangegeven, al telefonisch benaderd.

Voor het uitvoeren van het telefonisch onderzoek onder de non-respondenten is dit jaar gebruik gemaakt van één vragenlijst voor alle onderwijssoorten. Aan de hand van die lijst is informatie verzameld over de gevolgde opleiding van de non-respondent, over de belangrijkste bezigheid op het moment van enquêteren en (indien van toepassing) over de huidige baan. Aan alle nonrespondenten is tevens gevraagd naar de reden waarom men in eerste instantie niet heeft deelgenomen aan het onderzoek. Daarnaast zijn er enige vragen gesteld over de geboden mogelijkheid voor het invullen van de vragenlijst via internet. ${ }^{9}$

Tabel 5.1 laat per onderwijssoort zien wat de redenen van weigering door de non-respondenten zijn geweest. Hierbij gaat het dus om de non-respondenten die in eerste instantie niet hebben deelgenomen aan het onderzoek, maar wel aan de telefonische enquête. De belangrijkste reden waarom schoolverlaters de vragenlijst niet hebben ingevuld en teruggestuurd is dat het invullen ervan teveel tijd of moeite kost.

Tabel 5.1

Redenen van schoolverlaters om de schriftelijke vragenlijst niet in te vullen en terug te sturen in percentages per onderwijssoort

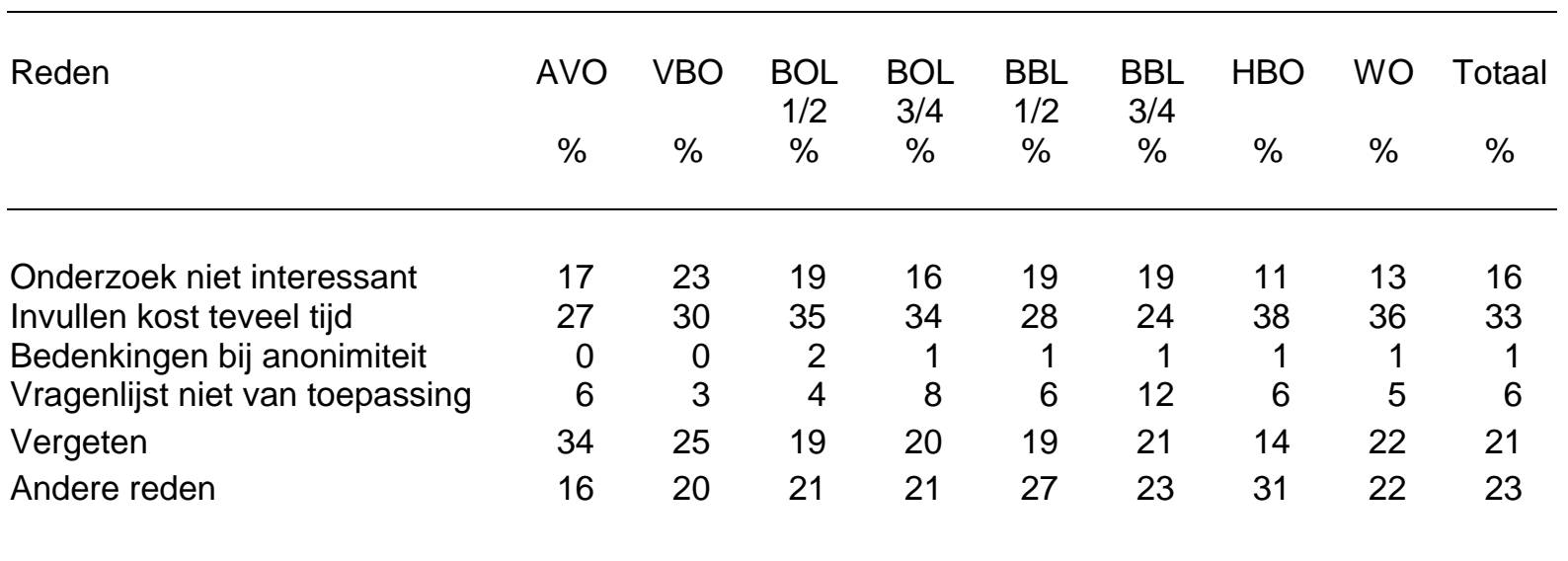

Om die reden worden voor het komende meetjaar (SIS 2002) de vragenlijsten voor AVO, VBO, $\mathrm{BOL}$ en BBL (RUBS) aanzienlijk ingekort. Bij de HBO-Monitor en de WO-Monitor wordt eveneens een kortere vragenlijst ontwikkeld. Deze wordt voor het meetjaar 2002 vooralsnog aan

9. Omdat de opzet van het non-responsonderzoek enigszins gewijzigd is zal er binnenkort een apart werkdocument verschijnen waarin uitvoeriger wordt ingegaan op het non-responsonderzoek. 
een beperkte groep (zo'n 10\% van de onderzoekspopulatie) afgestudeerden van het HBO en het WO gestuurd.

\section{Toets op selectiviteit}

Vervolgens kan worden nagegaan of de responsgroep en de groep die (aanvankelijk) niet op de schriftelijke enquête heeft gereageerd van elkaar verschillen voor wat betreft de kernvariabelen 'bestemming' en 'betaald werk'. De significantie van dit verschil wordt bepaald aan de hand van de toets van Fisher. Voordat deze Fisher-toets kan worden toegepast, is het echter noodzakelijk om enkele aanpassingen in de databestanden van zowel de non-responsgroep als de responsgroep door te voeren. Allereerst zijn de afgestudeerden van het kunstonderwijs en het hoger pedagogisch onderwijs die telefonisch gereageerd hebben, overgeheveld van de responsgroep naar de non-responsgroep. Voor onderzoeksdoeleinden behoren ze weliswaar tot de normale respons, maar gezien het feit dat ze de schriftelijke vragenlijst niet hebben geretourneerd, worden ze in het non-respons onderzoek beschouwd als non-respons.

Verder is de verdeling naar opleidingssector verschillend tussen het responsbestand en het nonresponsbestand. Om hiervoor te corrigeren - en dus beide bestanden op dit punt vergelijkbaar te maken - is het responsbestand zodanig (opnieuw) gewogen dat de verdeling over de opleidingssectoren overeenkomt met die van het non-responsbestand. ${ }^{10}$ Tabel 5.2 laat per onderwijssoort voor elke bestemmingscategorie het resultaat van de toets van Fisher zien. Voor de volledigheid is aangegeven hoe de bestemming van de non-responsgroep en de responsgroep er in aantallen en percentages uit ziet. De aantallen voor de responsgroep zijn daarbij, zoals gezegd, zodanig aangepast dat de verdeling van de schoolverlaters over de opleidingssectoren binnen de desbetreffende onderwijssoort gelijk is aan de verdeling binnen deze onderwijssoort in het non-responsbestand. ${ }^{11}$

De aantallen in de twee kolommen vormen de basis voor het berekenen van de z-score. Wat opvalt in tabel 5.2 is dat met name op VBO- en HBO-niveau veel significante verschillen zijn tussen de non-respons en de responsgroep. Binnen het VBO beschikt de non-responsgroep over significant meer mensen die werken of werkend leren (BBL). Terwijl er minder mensen een studie volgen in vergelijking met de responsgroep. Bij het HBO bevat de groep nonrespondenten significant meer werkenden, en significant minder personen die zich als studerend of werkloos beschouwen. Dit valt gedeeltelijk te verklaren door de grote aantallen respondenten die zijn ondervraagd.

Eventuele selectiviteit tussen de respons en de non-responsgroep in het antwoord op de vraag 'Heb je op dit moment (ook) betaald werk? (inclusief een betaalde bijbaan en/of een leerarbeidsplaats)' staat weergegeven in tabel 5.3. De term betaald werk in tabel 5.2 is overigens

10. In principe zou het ook mogelijk zijn geweest om het non-responsbestand te herwegen naar het (al dan niet gewogen) responsbestand. Aangezien het non-responsbestand sterk scheef verdeeld is over de opleidingssectoren, zou dit leiden tot zeer hoge en dus onbetrouwbare weegfactoren.

11. Uiteraard zou men de verdelingen nog meer op elkaar kunnen afstemmen door bijvoorbeeld ook rekening te houden met het kenmerk geslacht. Dit is echter niet gedaan, omdat de aantallen in het non-responsbestand daarvoor te klein zijn. 
niet dezelfde als het aandeel betaald werkenden waarnaar in tabel 5.3 wordt gekeken. Tabel 5.2 heeft betrekking op de activiteit die respondenten als hun belangrijkste bezigheid ervaren, terwijl er in tabel 5.3 wordt gekeken of iemand betaald werk heeft of niet, ongeacht of men dit de belangrijkste bezigheid vindt. Uit tabel 5.3 blijkt dat bij het VBO, BOL niveau 3/4 en het HBO de non-responsgroep over significant meer betaald werkenden beschikt dan de responsgroep.

Tabel 5.2

Toets van Fisher op selectiviteit naar bestemming tussen respondenten en non-respondenten per onderwijssoort

\begin{tabular}{|c|c|c|c|c|c|}
\hline \multirow[t]{2}{*}{ Bestemming } & \multicolumn{2}{|c|}{ Non-respons ${ }^{a}$} & \multicolumn{2}{|c|}{ Respons $^{\mathrm{b}, \mathrm{c}}$} & \multirow[t]{2}{*}{ Z-score } \\
\hline & aantal & $\%$ & aantal & $\%$ & \\
\hline \multicolumn{6}{|l|}{ AVO } \\
\hline LLW / in-service & 9 & 6 & 99 & 5 & 0,77 \\
\hline betaald werk & 22 & 15 & 202 & 10 & $2,08^{*}$ \\
\hline studie & 114 & 78 & 1.706 & 82 & $-1,17$ \\
\hline werkloos & & & 19 & 1 & $-1,16$ \\
\hline anders & 1 & 1 & 56 & 3 & $-1,48$ \\
\hline \multicolumn{6}{|l|}{ VBO } \\
\hline LLW / in-service & 59 & 23 & 613 & 17 & $2,52^{*}$ \\
\hline betaald werk & 93 & 37 & 1.036 & 29 & $2,65^{\star \star}$ \\
\hline studie & 94 & 37 & 1.681 & 47 & $-3,00^{* \star}$ \\
\hline werkloos & 5 & 2 & 89 & 3 & $-0,50$ \\
\hline anders & 2 & 1 & 166 & 5 & $-2,89^{* *}$ \\
\hline \multicolumn{6}{|l|}{$B O L 1 / 2$} \\
\hline LLW / in-service & 15 & 11 & 133 & 7 & 1,77 \\
\hline betaald werk & 79 & 57 & 1.157 & 59 & $-0,54$ \\
\hline studie & 37 & 27 & 445 & 23 & 1,04 \\
\hline werkloos & 5 & 4 & 100 & 5 & $-0,79$ \\
\hline anders & 3 & 2 & 120 & 6 & $-1,93$ \\
\hline \multicolumn{6}{|l|}{$B O L 3 / 4$} \\
\hline LLW / in-service & 10 & 5 & 63 & 2 & $2,46^{*}$ \\
\hline betaald werk & 135 & 69 & 1.710 & 62 & 1,94 \\
\hline studie & 45 & 23 & 863 & 31 & $-2,43^{*}$ \\
\hline werkloos & 2 & 1 & 37 & 1 & $-0,38$ \\
\hline anders & 4 & 2 & 88 & 3 & $-0,89$ \\
\hline \multicolumn{6}{|l|}{$B B L 1 / 2$} \\
\hline LLW / in-service & 19 & 11 & 182 & 7 & 1,65 \\
\hline betaald werk & 140 & 80 & 2.007 & 82 & $-0,59$ \\
\hline studie & 8 & 5 & 86 & 4 & 0,73 \\
\hline werkloos & 4 & 2 & 46 & 2 & 0,38 \\
\hline anders & 4 & 2 & 133 & 5 & $-1,80$ \\
\hline \multicolumn{6}{|l|}{$B B L 3 / 4$} \\
\hline LLW / in-service & 10 & 5 & 54 & 2 & $2,93^{\star \star}$ \\
\hline betaald werk & 166 & 89 & 2.237 & 89 & $-0,25$ \\
\hline studie & 5 & 3 & 80 & 3 & $-0,28$ \\
\hline werkloos & 1 & 1 & 30 & 1 & $-0,76$ \\
\hline anders & 4 & 2 & 134 & 5 & $-1,8$ \\
\hline
\end{tabular}


Tabel 5.2 (vervolg)

Toets van Fisher op selectiviteit naar bestemming tussen respondenten en non-respondenten per onderwijssoort

\begin{tabular}{|c|c|c|c|c|c|}
\hline \multirow[t]{2}{*}{ Bestemming } & \multicolumn{2}{|c|}{ Non-respons ${ }^{a}$} & \multicolumn{2}{|c|}{ Respons $^{\mathrm{b}, \mathrm{c}}$} & \multirow[t]{2}{*}{ Z-score } \\
\hline & aantal & $\%$ & aantal & $\%$ & \\
\hline \multicolumn{6}{|l|}{$H B O$} \\
\hline betaald werk & 1.486 & 92 & 18.307 & 83 & $9,37^{\star *}$ \\
\hline studie & 88 & 6 & 2.678 & 12 & $-8,10^{* *}$ \\
\hline werkloos & 14 & 1 & 377 & 2 & $-2,57^{*}$ \\
\hline anders & 26 & 2 & 653 & 3 & $-3,15^{\star *}$ \\
\hline \multicolumn{6}{|l|}{ WO } \\
\hline betaald werk & 398 & 92 & 5.292 & 91 & 1,50 \\
\hline studie & 15 & 4 & 187 & 3 & 0,32 \\
\hline werkloos & 10 & 2 & 127 & 2 & 0,42 \\
\hline anders & 8 & 2 & 214 & 4 & $-4,24^{\star *}$ \\
\hline
\end{tabular}

a. Inclusief telefonische respons (kunst- en pedagogisch onderwijs)

b. Exclusief telefonische respons (kunst- en pedagogisch onderwijs)

c. Gewogen naar de verdeling over de opleidingssectoren in het non-responsbestand. De hier gepresenteerde aantallen wijken derhalve af van de in de (landelijke) rapportages genoemde aantallen

* Significant op 5\%-niveau

** Significant op 1\%-niveau

Tabel 5.3

Toets van Fisher op selectiviteit in het aandeel betaald werkende respondenten en het aandeel betaald werkende non-respondenten per onderwijssoort

\begin{tabular}{|c|c|c|c|c|c|}
\hline Betaald werk & \multicolumn{2}{|c|}{ Non-respons ${ }^{a}$} & \multicolumn{2}{|c|}{ Respons $^{\mathrm{b}, \mathrm{c}}$} & Z-score \\
\hline \multicolumn{6}{|l|}{ AVO } \\
\hline ja & 102 & 69 & 1.426 & 69 & 0,17 \\
\hline nee & 45 & 31 & 649 & 31 & \\
\hline \multicolumn{6}{|l|}{ VBO } \\
\hline ja & 219 & 86 & 2.478 & 71 & $5,12^{* *}$ \\
\hline nee & 36 & 14 & 1.014 & 29 & \\
\hline \multicolumn{6}{|l|}{$B O L 1 / 2$} \\
\hline ja & 121 & 87 & 1.600 & 82 & 1,57 \\
\hline nee & 18 & 13 & 357 & 18 & \\
\hline \multicolumn{6}{|l|}{$B O L 3 / 4$} \\
\hline ja & 180 & 91 & 2.247 & 83 & $3,10^{\star *}$ \\
\hline nee & 17 & 9 & 465 & 17 & \\
\hline \multicolumn{6}{|l|}{$B B L 1 / 2$} \\
\hline ja & 170 & 96 & 2.312 & 94 & 1,13 \\
\hline nee & 7 & 4 & 148 & 6 & \\
\hline
\end{tabular}


Tabel 5.3 (vervolg)

Toets van Fisher op selectiviteit in het aandeel betaald werkende respondenten en het aandeel betaald werkende non-respondenten per onderwijssoort

Betaald werk $\begin{array}{lll}\text { Non-respons }^{\mathrm{a}} & \begin{array}{l}\text { Respons }^{\mathrm{b}, \mathrm{c}} \\ \text { aantal } \%\end{array} & \begin{array}{l}\text { aantal } \% \\ \text { aantal }\end{array}\end{array} \quad$ Z-score

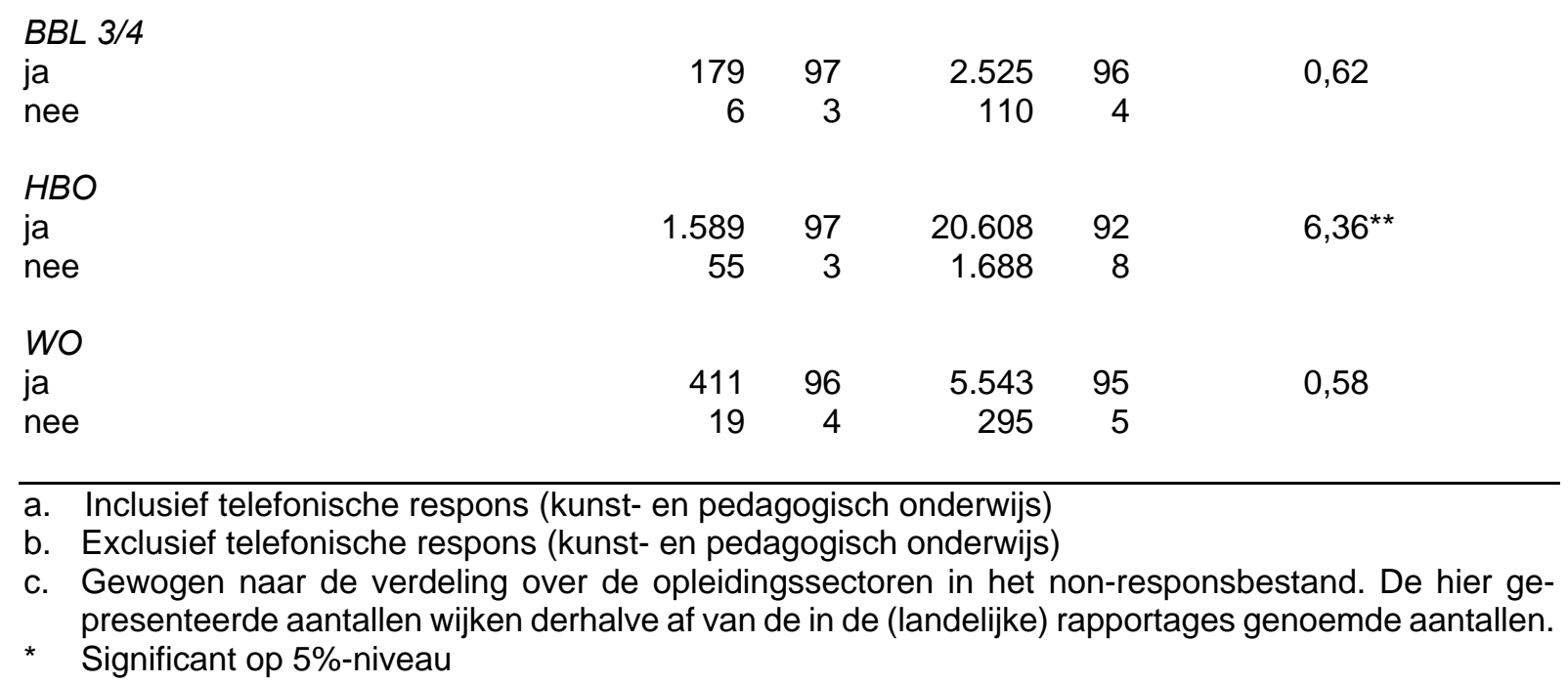

\section{Besluit}

In dit werkdocument is de methodiek beschreven van het Schoolverlatersinformatiesysteem (SIS) dat door het ROA in 2001 is uitgevoerd. Naast een overzicht van de opzet van dit onderzoek, de gehanteerde classificaties en de uitgevoerde controles en toegepaste correcties op het databestand, is vooral ingegaan op de dekkingsgraad, de respons en op het non-responsonderzoek.

Uit het gepresenteerde overzicht van de dekkingsgraad blijkt dat het schoolverlatersonderzoek over het algemeen zeer grootschalig van opzet is. Evenals de voorgaande jaren is alleen in het AVO en het VBO is er sprake van een lage dekkingsgraad (respectievelijk 6\% en 10\%).

De respons is het hoogst onder de AVO schoolverlaters (51\%). Evenals de afgelopen jaren is het responspercentage het laagst bij de afgestudeerden BBL niveau 1/2 (24\%). Uit de responsanalyse blijkt dat schoolverlaters van het AVO en het WO het vaakst responderen. Daarnaast leidt het decentraal verzenden van de vragenlijsten tot een hogere respons dan het centraal verzenden. Het blijkt eveneens dat men in het Westen van het land, evenals voorgaande jaren, minder respondeert dan in de overige regio's.

De belangrijkste reden voor het niet deelnemen aan de enquête is dat het teveel tijd en moeite kost. Om deze reden wordt voor het uitvoeringsjaar 2002 een aantal lijsten aanzienlijk ingekort. Wanneer gekeken wordt naar de selectiviteit tussen de respons- en de non-responsgroep blijkt dat met betrekking tot de bestemming van de schoolverlaters er bij het VBO en het HBO er 
regelmatig sprake is van significante verschillen. Voor zowel het VBO als het $\mathrm{HBO}$ geldt dat de non-responsgroep over meer werkenden beschikt. Voor het VBO, BOL niveau 3/4 en het HBO geldt ten slotte dat de non-responsgroep over een groter aandeel betaald werkenden beschikt dat de responsgroep.

\section{Literatuur}

Willems, E.J.T.A., A.S.R. van der Linden (1998), Methodiek schoolverlatersinformatiesysteem 1996, ROAW-1998/1, Maastricht.

Tribe, J. (1996), Core Skills: a Critical Examintion, in: Educational Review, 48 (1), pp.13-27.

Nijdam, B., H. van Buuren (1995), Statistiek voor de sociale wetenschappen, Samson Bedrijfsinformatie Alphen aan den Rijn. 



\section{Appendix A: Kernvragenlijst}

Tabel A.1

Overzicht kernvragen Schoolverlatersinformatiesysteem

Variabele

Opmerking

\section{Algemeen}

Geslacht

Leeftijd

Allochtoon

Toestemming doorgeven gegevens aan school

\section{Onderwijsloopbaan}

Gevolgde opleiding

Voltijd- of deeltijdvariant van gevolgde opleiding

Begindatum gevolgde opleiding

Einddatum gevolgde opleiding

Diploma of certificaat behaald van gevolgde opleiding

Opnieuw kiezen van gevolgde opleiding

Hoogste vooropleiding

Vooropleiding voor hoogste vooropleiding

Vervolgopleiding

Voltijd- of deeltijdvariant van vervolgopleiding

Vervolgopleiding diploma/gestopt

Plaats van vervolgopleiding

Aansluiting vervolgopleiding op gevolgde opleiding

Cursus/bedrijfsopleiding

Cursus/bedrijfsopleiding totale duur

Cursus/bedrijfsopleiding aantal uren per week

$\mathrm{HBO} / \mathrm{WO}$

niet IVBO wel MBO/HBO/WO

MBO (beperkt)/HBO/WO

$\mathrm{MBO} / \mathrm{HBO} / \mathrm{WO}$

$\mathrm{HBO} / \mathrm{WO}$

$\mathrm{HBO} / \mathrm{WO}$

AVO/MBO

niet WO

niet voor AVO

$\mathrm{MBO} / \mathrm{HBO} / \mathrm{WO}$

$\mathrm{MBO} / \mathrm{HBO} / \mathrm{WO}$

$\mathrm{MBO} / \mathrm{HBO} / \mathrm{WO}$

bij kunst zowel betaalde als onbetaalde werkkringen

$\mathrm{MBO} / \mathrm{HBO} / \mathrm{WO}$

niet IVBO/(I)VBO groen en VAVO

niet $\mathrm{AVO}$ wel $\mathrm{MBO} / \mathrm{HBO}$

HAO en WO LUW

niet bij AVO

HAO en WO LUW

Huidige functie vereiste opleidingsrichting volgens schoolverlater

Huidige functie leidinggeven

Huidige functie arbeidsuren per week

Huidige functie bruto maandinkomen 
Tabel A.1 (vervolg)

Overzicht kernvragen Schoolverlatersinformatiesysteem

Variabele

Opmerking

Huidige functie aansluiting met gevolgde opleiding

Nevenfuncties

Nevenfuncties aantal uren per week

Opleiding-huidige functie: belang van kennis en technieken

Opleiding-huidige functie: belang van vaardigheden

Opleiding-huidige functie: belang van houdingsaspecten

$\mathrm{MBO}$ (beperkt)/HBO/WO

$\mathrm{MBO} / \mathrm{HBO} / \mathrm{WO}$

$\mathrm{MBO} / \mathrm{HBO} / \mathrm{WO}$

Opleiding-huidige functie: aandacht voor kennis en technieken

$\mathrm{MBO}$ (beperkt)/HBO/WO

$\mathrm{MBO}$ (beperkt)/HBO/WO

MBO (beperkt)/HBO/WO

Opleiding-huidige functie: aandacht voor vaardigheden

MBO (beperkt)/HBO/WO

Opleiding-huidige functie: aandacht voor houdingsaspecten

$\mathrm{MBO}$ (beperkt)/HBO/WO

MBO (beperkt)/HBO/WO 